\title{
Correction to: Carry Trade Returns and Segmented Risk Pricing
}

\section{Gordon Schulze ${ }^{1}$}

Published online: 28 April 2021

(C) The Author(s) 2021

\section{Correction to: Atl Econ J https://doi.org/10.1007/s11293-021-09698-2}

The initial online publication contained several typesetting errors. The original article has been corrected.

Funding Open Access funding enabled and organized by Projekt DEAL.

Open Access This article is licensed under a Creative Commons Attribution 4.0 International License, which permits use, sharing, adaptation, distribution and reproduction in any medium or format, as long as you give appropriate credit to the original author(s) and the source, provide a link to the Creative Commons licence, and indicate if changes were made. The images or other third party material in this article are included in the article's Creative Commons licence, unless indicated otherwise in a credit line to the material. If material is not included in the article's Creative Commons licence and your intended use is not permitted by statutory regulation or exceeds the permitted use, you will need to obtain permission directly from the copyright holder. To view a copy of this licence, visit http://creativecommons.org/licenses/ by/4.0/.

Publisher's Note Springer Nature remains neutral with regard to jurisdictional claims in published maps and institutional affiliations.

The original article can be found online at https://doi.org/10.1007/s11293-021-09698-2.

Gordon Schulze

gordon.max.schulze@gmail.com

1 Faculty of Economics and Management, Department of Banking and Finance, Guericke

University Magdeburg, Postbox 4120, Otto von, 39016 Magdeburg, Germany 